\title{
Eat the meat or feed the meat: protein turnover in remodeling muscle
}

Citation for published version (APA):

Hesselink, M. K., Minnaard, R., \& Schrauwen, P. (2006). Eat the meat or feed the meat: protein turnover in remodeling muscle. Current Opinion in Clinical Nutrition and Metabolic Care, 9(6), 672-676. https://doi.org/10.1097/01.mco.0000247471.64532.7d

Document status and date:

Published: 01/01/2006

DOI:

10.1097/01.mco.0000247471.64532.7d

Document Version:

Publisher's PDF, also known as Version of record

Document license:

Taverne

Please check the document version of this publication:

- A submitted manuscript is the version of the article upon submission and before peer-review. There can be important differences between the submitted version and the official published version of record.

People interested in the research are advised to contact the author for the final version of the publication, or visit the DOI to the publisher's website.

- The final author version and the galley proof are versions of the publication after peer review.

- The final published version features the final layout of the paper including the volume, issue and page numbers.

Link to publication

\footnotetext{
General rights Owners
rights.

- You may freely distribute the URL identifying the publication in the public portal. please follow below link for the End User Agreement:

www.umlib.nl/taverne-license

Take down policy

If you believe that this document breaches copyright please contact us at:

repository@maastrichtuniversity.nl

providing details and we will investigate your claim.
}

Copyright and moral rights for the publications made accessible in the public portal are retained by the authors and/or other copyright owners and it is a condition of accessing publications that users recognise and abide by the legal requirements associated with these

- Users may download and print one copy of any publication from the public portal for the purpose of private study or research.

- You may not further distribute the material or use it for any profit-making activity or commercial gain

If the publication is distributed under the terms of Article $25 \mathrm{fa}$ of the Dutch Copyright Act, indicated by the "Taverne" license above, 


\section{Eat the meat or feed the meat: protein turnover in remodeling muscle \\ Matthijs K.C. Hesselink ${ }^{\mathrm{a}}$, Ronnie Minnaard ${ }^{\mathrm{a}}$ and Patrick Schrauwen ${ }^{\mathrm{b}}$}

\begin{abstract}
Purpose of review
The present review outlines the role of muscle protein turnover in muscle remodeling, with emphasis on the effects of nutrition and exercise.

\section{Recent findings}

Progress in our understanding of the pathways signaling and regulating protein synthesis and degradation, and thus protein turnover, in skeletal muscle has been substantial over the past decade. Protein synthesis and degradation jointly allow the active remodeling of skeletal muscle to adapt to changes in mechanical and metabolic demand. Nutrition and exercise are potent ways to stimulate protein turnover. This occurs in an amino acid and exercise-type (resistance versus endurance) and mode (lengthening and shortening)-specific manner.
\end{abstract}

\section{Summary}

For optimal muscle remodeling, the timing and type of feeding and exercise appear to be crucial.

\section{Keywords}

exercise, nutrition, protein degradation, protein synthesis

Curr Opin Clin Nutr Metab Care 9:672-676. (C) 2006 Lippincott Williams \& Wilkins.

aNutrition and Toxicology Research Institute Maastricht (NUTRIM), Department of Movement Sciences and ${ }^{b}$ Department of Human Biology, Maastricht University, the Netherlands

Correspondence to Matthijs K.C. Hesselink, Department of Movement Sciences, Maastricht University, PO Box 616, 6200 MD Maastricht, the Netherlands Tel: +31 43 3881317; fax: +3143 3670972;

e-mail: matthijs.hesselink@bw.unimaas.nl

Sponsorship: M.K.C.H. is supported by a VIDI grant for innovative research from the Netherlands Organization for Scientific Research (grant 917.66.359). P.S. is supported by a grant from the Dutch Royal Academy of Arts and Sciences.

Current Opinion in Clinical Nutrition and Metabolic Care 2006, 9:672-676

\section{Abbreviations}

Akt/PKB-mTOR Akt/protein kinase B-mammalian target of rapamycin AMPK adenosine monophosphate kinase
(C) 2006 Lippincott Williams \& Wilkins 1363-1950

\section{Introduction}

In healthy humans, skeletal muscle comprises approximately $50 \%$ of total body mass. Skeletal muscle is essential for gait and posture, and is fueled by multiple metabolic processes residing within the muscle. Skeletal muscle accounts for almost $80 \%$ of the basal metabolic rate [1]; in addition, skeletal muscle is responsible for approximately $80 \%$ of postprandial glucose uptake [2]. Skeletal muscle is obviously an important organ for locomotory and metabolic control. Muscular proteins are continuously subjected to (changes in) mechanical and metabolic demand, resulting in the remodeling of muscle. This requires a continuous tuned degradation and (re)synthesis of muscular proteins, myofibrillar contractile as well as sarcoplasmic metabolic proteins under a wide variety of conditions. In muscle remodeling the modulation of protein turnover is therefore crucial to maintain muscle mass and function.

The level and 'quality' of myofibrillar and sarcoplasmic proteins present at any given time reflects the net balance of protein degradation ('eat the meat') and protein synthesis ('feed the meat'). For protein synthesis to occur the ability to incorporate exogenous (dietary) or endogenous amino acids into the protein pool is essential. During protein degradation, the activation of proteolytic machinery results in the release of amino acids from the muscles.

Both protein synthesis and protein degradation are affected by (mal)nutrition, physical (in)activity and mechanical (un)loading and the hormonal changes that parallel these processes. Here we aim to review briefly the role of muscle protein turnover in muscle remodeling, with a focus on the role of nutrition and exercise.

\section{Dietary modulation of muscle protein turnover}

It has been shown in humans that over $50 \%$ of the whole body protein synthesis rate was accounted for by skeletal muscle protein synthesis [3]. In the same study it was shown that muscle protein synthesis was doubled in the fed compared with the fasted state [3]. Similar observations (35\% increase in protein synthesis) have been made while infusing a mixed amino acid solution in humans after $4 \mathrm{~h}$ of fasting [4]. This clearly identifies amino acids as the main food component responsible for the increased rate of protein synthesis after meal 
ingestion. The stimulatory effect of individual amino acids on protein synthesis, however, appears to be amino acid-specific. Administration of the essential amino acids, phenylalanine or threonine, significantly increases muscle protein synthesis, whereas administration of nonessential amino acids, arginine, glycine, or serine, failed to do so [5]. Large doses of individual essential amino acids thus stimulate the muscle protein synthesis rate.

\section{Nutritional effects on muscle protein synthesis}

Whereas a dose-response relationship between supplemented amino acids and the stimulation of protein synthesis was anticipated, things have turned out to be more complex. The administration of modest doses of leucine resulted in increased muscular protein synthesis, with a simultaneous drop in intramuscular amino acid levels, suggesting the incorporation of these amino acids into the muscular protein pool [6]. It could thus be hypothesized that a transient extracellular increase in leucine upon infusion somehow results in the increased incorporation of intracellular amino acids into the protein pool. It has recently been shown that the infusion of incremental amounts of an amino acid mixture resulted in increased plasma levels of the essential amino acids infused. In turn, these plasma levels were related in a hyperbolic fashion to muscle protein synthesis rates, with similar increases in myofibrillar, sarcoplasmic and mitochondrial proteins. Strikingly, a modest drop in free intracellular essential amino acid levels was observed upon the infusion of amino acids [7]. These observations point towards a yet to be determined extracellular amino acid (most likely leucine) sensor, which signals to incorporate intracellular free amino acids into the muscular protein pool [8].

In healthy individuals, meal ingestion results in the secretion of insulin, a hormone with recognized anabolic effects in rodents and in in-vitro assays [9]. In vivo in humans it has been shown that the addition of protein hydrolysates or amino acids to carbohydrate solutions potentiates insulin secretion in an amino acid-specific manner [10]. Combined with observations of a stimulated protein synthesis rate under physiological hyperinsulinemia [11], the administration of insulinogenic amino acid solutions may thus be advocated to augment muscle protein synthesis.

Again, however, things appear to be more complicated. Studies in which the pancreatic response to insulinogenic substances was blunted by the administration of octreotide have shown that exogenous amino acids stimulate the muscle protein synthesis rate to a similar extent under both basal and hyperinsulinemic conditions [12*0]. Therefore, it appears premature to attribute the potentiating effect of amino acids on protein synthesis directly to insulin.
Clearly, increasing the amino acid intake stimulates the muscle protein synthesis rate and results in muscle hypertrophy and increased muscle mass. The bulk of muscular proteins are myofibrillar proteins, involved in force generation. The supply of energy needed to generate force, however, relies on metabolic processes accounted for by sarcoplasmic proteins such as glycolytic enzymes and mitochondrial proteins facilitating aerobic processes. It would thus be of relevance to examine whether increased amino acid intake specifically affects myofibrillar, sarcoplasmic or mitochondrial protein synthesis. This however, does not appear to be the case $[8,13,14]$.

In summary, it seems safe to state that amino acids are capable of stimulating protein synthesis in an amino acidspecific manner, with essential amino acids being the most potent. Enhancing protein synthesis rates by the administration of amino acids does not occur in a dosespecific manner. The sensing of exogenous amino acids (mainly leucine) may signal to the pool of endogenously (intracellularly) available amino acids, which then are incorporated into muscular proteins. Therefore, rather than the absolute level of exogenously available amino acids, the pool of intracellularly available amino acids appears to be of importance. The role of insulin with respect to the protein synthesis rate is equivocal but may rely on indirect rather than direct effects.

\section{Nutritional effects on muscle protein degradation}

Selective protein degradation in eukaryotic cells occurs mainly via the ubiquitin-proteasome pathway [15]. In brief, this pathway selectively recognizes damaged, redundant and misfolded proteins that are tagged by the polypeptide ubiquitin in a process catalysed by E1 (ubiquitin-activating), E2 (ubiquitin-conjugating) and E3 (ubiquitin-ligating) enzymes. Polyubiquitinated proteins are targeted to the $26 \mathrm{~S}$ proteasome, comprising a $19 \mathrm{~S}$ regulatory domain that recognizes polyubiquitinated proteins and a $20 \mathrm{~S}$ proteolytic domain, which hydrolyzes proteins to peptides of typically 4-25 amino acids [16].

An examination of muscle protein degradation in humans and in vivo is complicated by limitations in the validity or sensitivity of the methodology available. Classic markers for muscle proteolysis such as the urinary excretion of 3-methyl histidine are biased by the high turnover of, for example, gastrointestinal smooth muscle cells, and in-vivo measures of endogenous leucine release in the circulation also reflect whole-body protein degradation rather than (skeletal) muscle-specific proteolysis. Therefore, the majority of the data available are derived from animal and in-vitro studies. These studies clearly point towards increased muscular protein degradation by the ubiquitin-proteasome pathway during long-term fasting [17], with increased rates of ubiquitination 
and the induction of gene expression and increased protein levels of the major components involved $[18,19]$. The routes resulting in activation of the ubiquitin-proteasome pathway in muscle during fasting, however, remain largely unknown. Under conditions of nutrient restriction it has been shown that increased proteasomal activity serves to provide amino acids to maintain protein synthesis and thus cell survival of vital organs $\left[20^{\bullet \bullet}\right]$. During feeding, when the net protein balance is positive, a modest reduction of approximately $12 \%$ in protein degradation has been reported after amino acid infusion [4], whereas protein synthesis rates may double [8]. Although quantitatively the contribution of protein degradation to net protein balance in the fed state may be minor, it is of importance to realize that protein synthesis is paralleled by increased levels of polypeptides that never attained native structure owing to errors in translation or posttranslational processes. These polypeptides are degraded by the ubiquitin-proteasome pathway [21]. This underscores the importance of maintaining a certain level of regulated, selective and targeted proteolytic activity to preserve muscle 'quality'.

Therefore, although data on nutritional effects on protein degradation are limited compared with the effects on protein synthesis, it is obvious that starvation triggers muscle proteolysis in a ubiquitin-proteasomedependent fashion, which may serve to maintain amino acid availability to vital organs. Feeding, on the contrary, blunts muscular protein degradation possibly via indirect antiproteolytic effects of insulin. The precise routes along which (insulin-induced) inhibition of the proteolytic system occurs remain to be elucidated.

\section{Physical (in)activity and muscle protein turnover}

Physical exercise and the concomitant metabolic changes are potent ways to enhance protein synthesis rates resulting in muscle hypertrophy. Insulin, amino acid and exercise-responsive signal transduction pathways in skeletal muscle have now been identified contributing to exercise-induced muscle hypertrophy. The Akt/ protein kinase $\mathrm{B}$-mammalian target of rapamycin (Akt/ $\mathrm{PKB}-\mathrm{mTOR}$ ) signaling pathway is the common denominator in these pathways. Activation of the Akt/PKBmTOR signal transduction pathway results in both the acute (within minutes to hours) and long-term (hours up to days) upregulation of protein synthesis through modulation of multiple steps involved in mediating the initiation of messenger RNA translation and ribosome biogenesis, respectively [22].

Mechanical loading associated with exercise contributes to muscle hypertrophy. Transsarcolemmal proteins physically connecting the extracellular matrix to sarcomeric protein muscle allow sensing of external load. For example, the giant sarcomere-spanning protein, titin, connected to the extracellular matrix via costamere structures and integrins, was found to possess kinase activity upon passive stretching, resulting in increased protein synthesis $\left[23^{\bullet \bullet}\right]$.

\section{Effects of activity on muscle protein synthesis}

Muscle growth after physical activity is more prominent after resistance exercise, whereas after endurance exercise changes towards slower more oxidative myofibrillar proteins and increased mitochondrial biogenesis are most striking. In an ex-vivo model of high-frequency stimulation to mimic resistance exercise, myofibrillar and sarcoplasmic protein synthesis increased by 5.3 and $2.7 \%$, respectively, within $3 \mathrm{~h}$. Low-frequency stimulation to mimic endurance exercise failed to affect the protein synthesis rate within the same time span, but did increase the activity of adenosine monophosphate kinase (AMPK) and gene expression of peroxisome proliferator-activated receptor-gamma coactivator-1 alpha (PGC 1- $\alpha$ ) [24*•], a key transcriptional co-factor in mitochondrial biogenesis. High-frequency stimulation acutely activated Akt/PKB and its downstream targets, resulting in prolonged activation of the translational regulators p70-S6k, 4EBP1, eIF-2B, and eEF2 without affecting the AMPKPGC- $1 \alpha$ signaling pathway. AMPK-PGC- $1 \alpha$ signaling thus seems to mediate adaptive responses to endurance training, whereas activating the Akt/PKB-mTOR pathway may underlie increased protein synthesis after resistance exercise. A human study examining the effect of training history (resistance versus endurance exercise) on signaling selectivity revealed that $3 \mathrm{~h}$ postexercise AMPK activity increased after cycling in resistance exerciseadapted but not endurance-trained individuals. Conversely, the activation of AMPK increased after resistance exercise in endurance but not strength-trained individuals. One hour of cycling increased Akt/PKB-mTOR signaling in endurance-trained, but not strength-trained individuals after cycling, but was unchanged in either group after resistance exercise [25*0. Exercise-type selective activation of distinct signaling cascades involved in protein synthesis have thus been observed in a training history-specific manner.

In-vitro data in mechanically stretched muscle cell activation revealed that specific types of mechanical stretch activate distinct signaling pathways [ $\left[26^{\circ}\right]$. In this respect, it has been hypothesized that differences in the direction and level of mechanical load of shortening versus lengthening contractions results in the activation of distinct signaling pathways. In a human model of short-term (12 min) stepping exercise, resulting in lengthening contraction in one leg and shortening contractions in the contralateral leg, protein synthesis rates were comparable across legs; however, differences in the signaling pathway could be not detected $\left[27^{\circ}\right]$. In a more sophisticated 
model, the same researchers again observed comparable increases in muscle protein synthesis during the $8.5 \mathrm{~h}$ period after shortening and lengthening exercise. The increased protein synthesis rate, however, peaked earlier following lengthening exercise [28 $8^{\bullet}$. This suggests that muscle protein synthesis can be further augmented by timed repetitive lengthening contractions. The anabolic power of lengthening exercise is further substantiated by the notion that activation of the anabolic signaling protein, p70-S6k, has been observed after a single session of maximal lengthening, even in the absence of a nutritional intake [29 $9^{\circ}$.

In conclusion, both the types of exercise (resistance exercise versus endurance exercise) and the mode of exercise (lengthening versus shortening) differentially affect the level of protein synthesis as well as the signaling routes involved.

\section{Effects of activity on muscle protein degradation}

As with protein synthesis, changes in muscular activity also affect protein degradation in a duration, intensity and mode of exercise-specific fashion. Two weeks of human limb casting followed by 6 weeks of exercise rehabilitation resulted in increases in gene expression of the $20 \mathrm{~S}$ proteasome and the muscle-specific proteolytic transcription factors, MAFbx and MuRF1 [30]. In rats, the induction of the same genes was observed within 5 days of limb casting, resulting in a significant loss of muscle mass [31]. Disuse atrophy in this model was rescued by the administration of a specific proteasome inhibitor indicating that the remodeling of immobilized skeletal muscle during atrophy is regulated by the ubiquitin-proteasome pathway [31]. The induction of proteasome-specific genes by immobilization was suppressed upon rehabilitation exercise, allowing the instigation of muscle hypertrophy and remodeling [30].

The importance of the ubiquitin-proteasome pathway in muscle remodeling upon exercise under non-atrophying conditions is less prominent. Although it seems plausible to hypothesize that during endurance training, which results in a shift towards more oxidative and less glycolytic myofibrillar proteins, the glycolytic isoforms are selectively targeted and degraded in a ubiquitinproteasome-dependent fashion, no studies are available that firmly underpin this hypothesis. For acetyl coenzyme A carboxylase, a key enzyme regulating fat oxidation, selective targeting of ubiquitin in a ubiquitin ligase E3-specific manner to acetyl co-enzyme A carboxylase has recently been shown in adipose tissue [32*0]. This unmasks a novel proteasome-dependent route coregulating lipid metabolism along with the more classic routes of kinase-dependent phosphorylation. Whether similar routes are present in muscle, whether they are affected by exercise, and whether they also exist for other 'metabolic master switches' is an intriguing, yet unanswered, question.

For protein degradation apparent differences have also been observed between shortening and lengthening exercise. Many studies have observed the involvement of the ubiquitin-proteasome pathway in postexercise remodeling after lengthening exercise, including increased ubiquitin-conjugated protein content [33], as well as increased gene and protein expression of the ubiquitin ligase E3 and the $20 \mathrm{~S}$ proteasome [34]. Interestingly, in a second session of lengthening exercise, the increase in proteolytic proteins was blunted, possibly reflecting a rapid and adaptive remodeling response to lengthening exercise [34]. A rapid and adaptive response to lengthening exercise is not restricted to myofibrillar proteins, but also includes remodeling of extracellular matrix $\left[28^{\bullet}, 35^{\bullet \bullet}, 36\right]$ and the intermediate filament lattice.

In summary, increased muscle protein degradation in a ubiquitin-proteasome-dependent fashion is of particular importance under unloading conditions. The vast majority of studies reporting exercise-induced blunting in protein degradation do so in models with negative net protein synthesis at the onset of exercise (limb casting, Duchenne muscle dystrophy, muscle damage, etc.). The few studies that examined the effect of exercise (either lengthening or shortening) on protein degradation in healthy individuals report no (shortening exercise) or less robust (lengthening exercise) effects on exercise-induced protein degradation. Importantly, recent data indicate that the targeted degradation of proteins involved in fuel selection may also serve to regulate substrate metabolism.

\section{Conclusion}

The maintenance of muscle mass and its ability to adapt to changes in metabolic demand is a tightly regulated process requiring simultaneous but tuned activity of protein synthesis and degradation. Both nutritional interventions [with essential (insulinogenic) amino acids as key components] and physical exercise stimulate net protein synthesis. These effects are mostly accounted for by the direct or indirect activation of protein synthesis, and to a lesser extent by the inhibition of protein degradation. Nevertheless, to maintain muscle quality and not solely muscle quantity, selective protein degradation is essential for the removal of redundant, damaged and misfolded proteins. Distinct signaling pathways have now been identified for endurance versus resistance exercise, possibly explaining the differential phenotypical effects of these types of exercise. For the mode of exercise (lengthening or shortening) distinct signaling pathways have been identified in cultured muscle cells, which so far could not be confirmed in humans. 
Exercise-induced blunting effects on protein degradation have mainly been examined in models in which exercise was superimposed in states when net protein synthesis was negative. Exercise-induced effects on protein degradation in situations of protein balance are equivocal.

\section{References and recommended reading}

Papers of particular interest, published within the annual period of review, have been highlighted as:

- of special interest

-• of outstanding interest

Additional references related to this topic can also be found in the Current World Literature section in this issue (p. 765).

1 Ravussin E, Lillioja S, Anderson TE, et al. Determinants of 24-h energy expenditure in man. Methods and results using a respiratory chamber. J Clin Invest 1986; 78:1568-1578.

2 DeFronzo RA, Gunnarsson R, Bjorkman O, et al. Effects of insulin on peripheral and splanchnic glucose metabolism in noninsulin-dependent (type II) diabetes mellitus. J Clin Invest 1985; 76:149-155.

3 Rennie MJ, Edwards RH, Halliday D, et al. Muscle protein synthesis measured by stable isotope techniques in man: the effects of feeding and fasting. Clin Sci (Lond) 1982; 63:519-523.

4 Bennet WM, Connacher AA, Scrimgeour CM, et al. Increase in anterior tibialis muscle protein synthesis in healthy man during mixed amino acid infusion: studies of incorporation of [1-13C] leucine. Clin Sci (Lond) 1989; 76:447-454.

5 Smith K, Reynolds N, Downie S, et al. Effects of flooding amino acids on incorporation of labeled amino acids into human muscle protein. Am J Physiol 1998; 275:E73-E78.

6 Alvestrand A, Hagenfeldt L, Merli M, et al. Influence of leucine infusion on intracellular amino acids in humans. Eur J Clin Invest 1990; 20:293-298.

7 Bohe J, Low A, Wolfe RR, et al. Human muscle protein synthesis is modulated by extracellular, not intramuscular amino acid availability: a dose-response study. J Physiol 2003; 552:315-324.

8 Rennie MJ. Body maintenance and repair: how food and exercise keep the musculoskeletal system in good shape. Exp Physiol 2005; 90:427-436.

9 Wolfe RR. Effects of insulin on muscle tissue. Curr Opin Clin Nutr Metab Care 2000; 3:67-71.

10 van Loon LJ, Saris $\mathrm{WH}$, Verhagen $\mathrm{H}$, et al. Plasma insulin responses after ingestion of different amino acid or protein mixtures with carbohydrate. Am J Clin Nutr 2000; 72:96-105.

11 Biolo G, Declan Fleming RY, Wolfe RR. Physiologic hyperinsulinemia stimulates protein synthesis and enhances transport of selected amino acids in human skeletal muscle. J Clin Invest 1995; 95:811-819.

12 Cuthbertson D, Smith K, Babraj J, et al. Anabolic signaling deficits underlie -. amino acid resistance of wasting, aging muscle. FASEB J 2005; 19:422-424. A report showing that exogenous amino acids stimulate protein synthesis independent of insulin, conserved basal rates of protein synthesis in elderly but decreased sensitivity and responsiveness to exogenous amino acids possibly linked to components of anabolic signaling pathways.

13 Louis M, Poortmans JR, Francaux M, et al. No effect of creatine supplementation on human myofibrillar and sarcoplasmic protein synthesis after resistance exercise. Am J Physiol Endocrinol Metab 2003; 285:E1089-E1094.

14 Bohe J, Low JF, Wolfe RR, et al. Latency and duration of stimulation of human muscle protein synthesis during continuous infusion of amino acids. J Physio 2001; 532:575-579.

15 Rock KL, Gramm C, Rothstein L, et al. Inhibitors of the proteasome block the degradation of most cell proteins and the generation of peptides presented on MHC class I molecules. Cell 1994; 78:761-771.

16 Voges D, ZwicklP, Baumeister W. The 26 S proteasome: a molecular machine designed for controlled proteolysis. Annu Rev Biochem 1999; 68:10151068.

17 Lecker SH, Solomon V, Mitch WE, et al. Muscle protein breakdown and the critical role of the ubiquitin-proteasome pathway in normal and disease states. J Nutr 1999; 129:227S-237S.

18 Wing SS, Haas AL, Goldberg AL. Increase in ubiquitin-protein conjugates concomitant with the increase in proteolysis in rat skeletal muscle during starvation and atrophy denervation. Biochem J 1995; $307(\mathrm{Pt} \mathrm{3}): 639-645$

19 Jagoe RT, Goldberg AL. What do we really know about the ubiquitin-proteasome pathway in muscle atrophy? Curr Opin Clin Nutr Metab Care 2001; 4:183-190.
20 Vabulas RM, Hartl FU. Protein synthesis upon acute nutrient restriction relies - on proteasome function. Science 2005; 310:1960-1963.

A report showing that amino acids for de-novo protein synthesis are derived from the degradation of preexisting proteins, whereas nascent and newly formed polypeptides remained largely protected from proteolysis. Proteasome inhibition during nutrient deprivation caused rapid amino acid depletion and marked impairment of translation, identifying the ubiquitin-proteosome pathway as a critical player with respect to cell survival during starvation.

21 Schubert U, Anton LC, Gibbs J, et al. Rapid degradation of a large fraction of newly synthesized proteins by proteasomes. Nature 2000; 404:770-774.

22 Bolster DR, Jefferson LS, Kimball SR. Regulation of protein synthesis associated with skeletal muscle hypertrophy by insulin-, amino acid- and exerciseinduced signalling. Proc Nutr Soc 2004; 63:351-356.

23 Lange S, Xiang F, Yakovenko A, et al. The kinase domain of titin controls muscle -. gene expression and protein turnover. Science 2005; 308:1599-1603.

A report showing the importance of the sensing of mechanical load by titin with respect to regulating protein turnover in muscle.

24 Atherton PJ, Babraj J, Smith K, et al. Selective activation of AMPK-PGC- 1alpha or PKB-TSC2-mTOR signaling can explain specific adaptive responses to endurance or resistance training-like electrical muscle stimulation. FASEB J 2005; 19:786-788.

The first report identifying distinct signaling pathways for resistance versus endurance exercise.

25 Coffey VG, Zhong Z, Shield A, et al. Early signaling responses to divergent -• exercise stimuli in skeletal muscle from well trained humans. FASEB J 2006; 20:190-192.

A report examining the effect of training history on the signaling responsiveness to resistance and endurance exercise.

26 Hornberger TA, Armstrong DD, Koh TJ, et al. Intracellular signaling specificity

- in response to uniaxial vs. multiaxial stretch: implications for mechanotransduction. Am J Physiol Cell Physiol 2005; 288:C185-C194.

Studies in cultured muscle cells showing that anabolic responses in muscle cells are sensitive to the direction of strain.

27 Cuthbertson DJ, Babraj J, Smith K, et al. Anabolic signaling and protein - $\quad$ synthesis in human skeletal muscle after dynamic shortening or lengthening exercise. Am J Physiol Endocrinol Metab 2006; 290:E731-E738.

A human study examining the effect of positive versus negative work on anabolic signaling pathways.

28 Moore DR, Phillips SM, Babraj JA, et al. Myofibrillar and collagen protein

- $\quad$ synthesis in human skeletal muscle in young men after maximal shortening and lengthening contractions. Am J Physiol Endocrinol Metab 2005; 288:E1153E1159.

A report showing exercise mode-specific effects on both myofibrillar and extracellular matrix protein synthesis.

29 Eliasson J, Elfegoun T, Nilsson J, et al. Maximal lengthening contractions

- increase p70S6 kinase phosphorylation in human skeletal muscle in the absence of nutritional supply. Am J Physiol Endocrinol Metab, 11 July 2006. E-pub ahead of print.

A report showing that activation of the anabolic signaling pathways upon lengthening exercise occurs without nutritional supply.

30 Jones SW, Hill RJ, Krasney PA, et al. Disuse atrophy and exercise rehabilitation in humans profoundly affects the expression of genes associated with the regulation of skeletal muscle mass. FASEB J 2004; 18:1025-1027.

31 Krawiec BJ, Frost RA, Vary TC, et al. Hindlimb casting decreases muscle mass in part by proteasome-dependent proteolysis but independent of protein synthesis. Am J Physiol Endocrinol Metab 2005; 289:E969-E980.

32 Qi L, Heredia JE, Altarejos JY, et al. TRB3 links the E3 ubiquitin ligase COP1 •• to lipid metabolism. Science 2006; 312:1763-1766.

An elegant work identifying a role for the ubiquitin-proteasome pathway in metabolic remodeling by the targeted degradation of fuel-sensing proteins next to the classically known routes of phosphorylation activation.

33 Stupka N, Tarnopolsky MA, Yardley NJ, et al. Cellular adaptation to repeated eccentric exercise-induced muscle damage. J Appl Physiol 2001; 91:16691678.

34 Willoughby DS, Taylor M, Taylor L. Glucocorticoid receptor and ubiquitin expression after repeated eccentric exercise. Med Sci Sports Exerc 2003; 35:2023-2031.

35 Kjaer $\mathrm{M}$, Langberg $\mathrm{H}$, Miller $\mathrm{BF}$, et al. Metabolic activity and collagen turnover - in human tendon in response to physical activity. J Musculoskelet Neuronal Interact 2005; 5:41-52.

One of the few papers focusing on extracellular matrix remodeling upon exercise, which is of importance because muscle cell growth also requires extracellular matrix remodeling.

36 Koskinen SO, Ahtikoski AM, Komulainen J, et al. Short-term effects of forced eccentric contractions on collagen synthesis and degradation in rat skeletal muscle. Pflugers Arch 2002; 444:59-72. 